\title{
PENGARUH CITRA PERUSAHAAN (CORPORATE IMAGE) DAN PENANGANAN KELUHAN (COMPLAINT HANDLING) TERHADAP LOYALITAS PELANGGAN (LOYALITY) NATASHA SKIN CARE DI KOTA PADANG
}

\author{
Gies Aprisia, Riri Mayliza \\ Sekolah Tinggi Ilmu Ekonomi "KBP" \\ ririmayliza@akbpstie.ac.id
}

\begin{abstract}
This research was conducted at Natasha Skin Care Branch of Padang. The purpose of this research are: 1) To know the influence of corporate image to customer loyalty in Natasha Skin Care, 2) To know the effect of complaint handling to customer loyalty in Natasha Skin Care. The type of this research is qualitative research. The object of this research is Natasha Skin Care Branch of Padang. Data analysis method used is descriptive analysis and multiple linear regression analysis. Based on the result of the research, the conclusion is as follows: 1), Corporate Image has an effect on loyalty of Natasha Skin Care Padang customer because the significance level is 0,000 smaller than the significant level 0,05 (Sig 0,000<0,05), it can be concluded that the image company partially influence to customer loyalty Natasha Skin Care Padang (HI accepted). 2), Complaint handling has negative and significant effect on customer loyalty Natasha Skin Care Padang because of the significance level 0.000 smaller than level of significant 0,05 (Sig 0,000 <0,05), hence can be concluded that complaint handling have negative and significant effect partially to customer loyalty Natasha Skin Care Padang (H2 accepted).
\end{abstract}

Keywords: Corporate Image, Complaint Handling and Customer Loyalty.

\section{PENDAHULUAN}

Kehidupan masyarakat dari waktu ke waktu semakin berkembang, ini ditandai dengan kebutuhan masyarakat yang dahulunya tradisional menjadi konvensional, mereka menginginkan segala hal menjadi instan.Perkembangan dunia usaha kecantikan ini telah diwarnai oleh persaingan yang semakin ketat. Hal ini diakibatkan karena adanya arus globalisasi yang semakin terbuka lebar bagi setiap pelaku bisnis. Timbulnya persaingan yang sangat ketat tersebut menyebabkan kalangan usaha saling berlomba untuk dapat menghadapi persaingan dan mendapatkan keunggulan kompetitif. Oleh karena hal tersebut setiap perusahaan dituntut agar mampu menciptakan produk dengan spesifikasi yang terbaik agar keinginan pelanggan dapat terpenuhi. 
Pemasaran bertujuan untuk membangun dan mempertahankan pelanggan yang dapat menguntungkan perusahaan. Sedangkan menurut Drucker tujuan perusahaan adalah untuk menciptakan pelanggan. Salah satu keunggulan bersaing yang paling efektif dalam bisnis berkarakteristik jasa adalah membina hubungan erat dengan pelanggan. Hubungan yang dekat dengan pelanggan dalam jangka panjang akan mendorong pihak-pihak yang terlibat dalam hubungan menemukan cara-cara terbaik dalam berinteraksi sehingga relationship cost dapat dikurangi dengan hubungan yang saling memuaskan antara kedua belah pihak.

Setiap perusahaan pasti akan berusaha memanfaatkan hubungan yang kuat antara perusahaan dengan pelanggan untuk mendapatkan informasi berharga tentang bagaimana cara terbaik untuk melayani pelanggan dan menjaga mereka agar tidak berpindah ke merak lain untuk bersaing merek. Dengan membangun hubungan dengan pelanggan, perusahaan juga bisa mendapatkan kualitas sumber-sumber intelijen pemasaran untuk perencanaan yang lebih baik..

Kehilangan pelanggan akan menjadi bencana di dalam pasar yang sudah matang, yakni pasar telah mengalami sedikit pertumbuhan nyata. Pelanggan merupakan faktor penting yang harus diperhatikan oleh perusahaan. Pelanggan merupakan aset yang dapat menentukan keberhasilan perusahaan, mengingat pelanggan mencerminkan potensi pertumbuhan pada masa yang akan datang. Usaha menciptakan dan mempertahankan pelanggan hendaknya menjadi prioritas yang lebih besar bagi perusahaan. Strategi yang tepat dapat menarik pelanggan hendaknya disusun secara cermat, agar pelanggan mau membeli produk atau jasa yang dihasilkan perusahaan. Lebih dari itu, dengan segala kiatnya perusahaan hendaknya juga terus berupaya agar pelanggan dapat menjadi pelanggan yang setia.

Bagi perusahaan, konsumen yang setia sangat besar artinya selain menggambarkan besarnya profitabilitas yang diperoleh. Pelanggan yang setia dapat menjadi partner dalam mengembangkan produk baru, karena mereka mempertahankan dan membela bahkan menggunakan pelayanan perusahaan yang ada. Sikap loyal pelanggan dengan cara melakukan pembelian secara berulang memperlihatkan bahwa pelanggan percaya pada produk pelayanan yang diberikan.

Menurut Darsono seorang pelanggan yang loyal menjadi asset yang sangat bernilai bagi perusahaan. Pelanggan yang loyal akan mengurangi usaha mencari pelanggan baru, memberikan umpan balik positif kepada perusahaan. Hal itu ditunjukkan dengan keinginan pelanggan atau konsumen untuk menggunakan jasa perusahaan secara terus-menerus atau berulang-ulang. Griffin mengatakan bahwa pelanggan yang loyal memiliki ciri-ciri antara lain melakukan pembelian secara berulang pada perusahaan yang sama, membeli lini produk dan jasa yang ditawarkan perusahaan, dan memberitahukan kepada orang lain tentang kepuasan-kepuasan yang diterimanya.

Seperti halnya perusahan jasa yang bergerak dibidang lain, contohnya transportasi, akomodasi, pariwisata, ekspedisi, dan lain-lain. Natasha Skin Care yang lebih berorientasi pada upaya untuk mengarahkan para pelanggan maupun calon pelanggan untuk lebih setia pada produk ataupun layanan jasa yang diberikan, dimana dengan kesetiaan yang tinggi dari konsumen serta diikuti dengan minat beli pada produk pada akhirnya juga akan berdampak pada peningkatan penjualan perusahaan. 
Natasha Skin Care sebagai salah satu pusat perawatan kecantikan yang pada beberapa tahun belakangan mampu "mencuri" hati para pelanggan di tengah maraknya industri jasa perawatan kecantikan. Natasha Skin Care yang berpusat di Yogyakarta ini, hanya dalam kurun waktu dua belas tahun saat ini sudah memiliki cabang di 40 kota di Indonesia. Di kota Padang sendiri misalnya memiliki satu cabang.

Untuk mempertahankan loyalitas pelanggannya, perusahaan ini terus melakukan berbagai terobosan baru seperti penggunaan alat-alat yang canggih dan modern, merumuskan visi dan misi, dan komitmennya. Natasha Skin Care misalnya sebagai pusat perawatan kecantikan kulit wajah yang memadukan teknologi tinggi terkini dalam perawatan kulit dan tenaga profesional. Pusat perawatan kecantikan tersebut memberikan berbagai jenis pelayanan kepada masyarakat khususnya dalam menjawab gaya hidup kaum wanita di perkotaan yang selalu menuntutnya untuk lebih memperhatikan penampilan. Tidak hanya dalam berbusana, namun juga penampilan kulit wajah dan tubuh. Artinya, penampilan diri seutuhnya (total look) menjadi sebuah kebutuhan penting untuk menunjang kepercayaan diri khususnya bagi seorang perempuan.Loyalitas pelanggan terhadap suatu produk dilandasi oleh faktor-faktor tertentu. Diantara berbagai faktor yang mempengaruhi loyalitas pelanggan adalah mengenai citra positif perusahaan dan adanya penanganan keluhan yang ramah.

Meskipun citra yang dibangun perusahaan mempengaruhi loyalitas pelanggan, akan tetapi aspek penanganan keluhan juga akan berperan dalam mempengaruhi hubungan citra dengan loyalitas pelanggan. Kesetiaan pelanggan terhadap perusahaan Natasha Skin Care dipengaruhi juga bagaimana perusahaan menangani berbagai keluhan pelanggannya. Loyalitas pelanggan Natasha Skin Care yang tidak begitu baik memperlihatkan bahwa kepercayaan pelanggan terhadap Natasha Skin Care dalam menangani keluhan pelanggan tidak begitu baik.

Atas dasar itu, perlu untuk melakukan kajian mengenai bagaimana upaya yang perlu dilakukan oleh pihak manajemen Natasha Skin Care untuk mengarahkan konsumen sehingga dapat meningkatkan penjualan di masa yang akan datang. Berdasarkan fenomena di atas, maka penulis melakukan penelitian dengan judul "Pengaruh Citra Perusahaan (Corporate Image) Dan Penanganan Keluhan (Complaint Handling) Terhadap Loyalitas Pelanggan (Loyality) Natasha Skin Care Di Kota Padang”.

\section{LANDASAN TEORI}

Behavioral Loyalty. Definisi awal dari loyalitas berfokus hampir secara keseluruhan pada dimensi behavioral. Secara khusus, loyalitas diinterpretasikan sebagai bentuk dari perilaku konsumen (seperti halnya pembelian berulang) langsung kepada merek tertentu selama beberapa waktu

Attitudinal Loyalty, secara khusus, mengkritisi konseptualisasi behavioral tentang loyalitas, dan berpendapat loyalitas merek dibangun sebagai hasil dari usaha sadar untuk mengevaluasi merek yang berkompetisi. Beberapa yang lainnya menambahkan dimensi sikap ini meliputi preferensi atau niat konsumen. 
Cognitive Loyalty, Sebagai tambahan pada dimensi behavioral dan sikap/attitudinal, beberapa ahli menambahkan apa yang disebut sebagai bentuk "kognitif" dari loyalitas.

Beberapa studi menyatakan loyalitas pada sebuah merek atau toko hadir terlebih dahulu dalam pikiran konsumen ketika kebutuhan untuk membuat keputusan tentang apa yang dibeli atau dimana membeli muncul (jill;2004). Berdasarkan berbagai literatur tersebut, Gremler et al. (2000) mendefinisikan loyalitas pada jasa terdiri atas tiga dimensi yang berbeda, namun saling berhubungan. Loyalitas pada jasa didefinisikan sebagai tingkatan dimana konsumen menunjukkan perilaku pembelian berulang dari sebuah penyedia jasa, mempunyai sikap yang positif terhadap perusahaan tersebut, dan mempertimbangkan hanya akan menggunakan perusahaan tersebut ketika kebutuhan akan jasa tersebut muncul.

Pelanggan berasal dari kata custom, yang didefinisikan sebagai "membuat sesuatu menjadi kebiasaan atau biasa" dan "mempraktikkan kebiasaan". Pelanggan adalah seseorang yang menjadi terbiasa untuk membeli dari anda. Kebiasaan itu terbentuk melalui pembelian dan interaksi yang sering selama periode waktu tertentu (Jill, 2005:31).

Berdasarkan Kamus Besar Bahasa Indonesia, pelanggan memiliki pengertian orang yang membeli (menggunakan) produk barang/jasa secara tetap.Definisi pelanggan memberikan pandangan mendalam yang penting untukmemahami mengapa perusahaan harus menciptakan dan memelihara pelanggandan bukan hanya menarik pembeli.Seseorang yang datang ke sebuah perusahaan, melakukan pembelianproduk barang/jasa dan penggunaan layanan dengan frekuensi yang lebih dari satukali dan berulang dapat dikategorikan sebagai pelanggan. Selain itu juga untukmengkategorikan apakah konsumen bisa dikategorikan sebagai pelanggan bisadibedakan menurut nilainya. Hal tersebut bertujuan untuk mengukur sejauh manakeuntungan total yang didapatkan perusahaan apabila melanjutkan transaksidengan pelanggan pada masa yang akan datang. Alat ukurnya ada dua yaituinteraksi dan transaksi.

Transaksi dipakai untuk mengukur sejauh mana trackrecord hubungan bisnis perusahaan dengan pelanggan. Pelanggan termasuk tipe yang suka menuntut atau tipe yang menyenangkan. Hal tersebut perlu diperhitungkan karena akan mempengaruhi biaya total yang harus dikeluarkan perusahaan untuk mempertahankan pelanggan. Sedangkan interaksi dipakai untuk mengukur sejauh mana kedekatan hubungan emosi yang terjalin selama ini dan sejauh mana tingkat komitmen pelanggan untuk melanjutkan kembali hubungan bisnis yang sudah terjalin pada masa yang akan datang (Kartajaya, 2007:126-127).

Pada dasarnya tujuan dari suatu bisnis adalah untuk menciptakan pelanggan agar merasa puas. Terciptanya kepuasan pelanggan dapat memberikan beberapa manfaat, diantaranya adalah hubungan antara perusahaan dan pelanggan menjadi harmonis, memberikan dasar yang baik bagi pelanggan untuk melakukan pembelian ulang dan terciptanya loyalitas pelanggan serta memberikan suatu bentuk rekomendasi dari mulut ke mulut yang menguntungkan perusahaan.

Berdasarkan Kamus Besar Bahasa Indonesia, loyalitas berasal dari kata "loyal" yang berarti patuh dan setia. Loyalitas merupakan fungsi dari tindakan dan 
sikap. Sikap yang merefleksikan keinginan untuk mempertahankan hubungan yang bermakna. Mengacu pada pengertian pelanggan dan loyalitas, maka loyalitas pelanggan dapat diartikan sebagai suatu sikap positif yang ditunjukkan pelanggan terhadap suatu perusahaan dengan bersedia membeli atau menggunakan secara berulang-ulang.

Setiap perusahaan termasuk perusahaan yang bergerak di bidang jasa(khususnya industri jasa kecantikan) perlu membangun citra untuk membuatperusahaan tersebut mempunyai nilai tambah (added value) di mata pelanggan.Terkait dengan pengertian citra perusahaan, banyak ahli telah memberikandefinisi berdasarkan perspektif masing-masing. Ruslan (2005:66) memberikanpengertian mengenai citra sebagai sesuatu yang abstrak (intangible) dan tidakdapat diukur secara nominal/matematis, tetapi wujud citra hanya bisa dirasakandari hasil penelitian/nilai yang baik atau buruk, tanggapan positif atau negatif.

Biasanya landasan citra itu berakar dari "nilai-nilai kepercayaan" yang konkretnyadiberikan secara individual, dan merupakan pandangan atau persepsi seseorang.Proses akumulasi dan amanah kepercayaan yang telah diberikan oleh individuindividutersebut akan mengalami proses cepat atau lambat untuk membentukopini publik yang lebih luas, yaitu sering dinamakan citra (Ruslan, 2005:67).

Pengertian citra juga dikemukakan Kotler (2000:127) yangmendefinisikannya sebagai jumlah dari keyakinan-keyakinan, gambaran-gambaran,dan kesan-kesan yang dipunyai seseorang pada suatu objek. Objekyang dimaksud bisa berupa orang, organisasi, kelompok orang atau yang lainnyayang diketahuinya. Apabila objek tersebut berupa organisasi, berarti seluruhkeyakinan, gambaran dan kesan atas organisasi dari seseorang merupakan citra

Setiap organisasi yang berorientasi pada pelanggan (customer-oriented) perlumenyediakan kesempatan dan akses yang mudah dan nyaman bagi para pelanggannya gunamenyampaikan saran, kritik, pendapat, dan keluhan mereka (Tjiptono 2005 h.210).Perilaku keluhan konsumen adalah istilah yang mencakup semua tindakan konsumenyang berbeda bila mereka merasa tidak puas dengan suatu pembelian/pelayanan.

(Sunarto 2006h.253)Ketika pelanggan mendapatkan masalah atau bahkan sedikit kecewa, maka perusahaan-perusahaanbesar dengan cepat menunjukkan jati dirinya. Pemulihan pelayanan juga bisaditangani dengan sangat baik ketika dipandang sebagai satu kesempatan bukan sebagai suatupilihan sulit. Keluhan pelanggan merupakan kesempatan untuk memperkuat hubungan (Bramson 2004 h.83). Menurut Andreassen (dalam Wijaya, 2008) ketidakpuasan yang diakibatkan adanyaperbedaan antara harapan dan kemampuan sesungguhnya dari sebuah produk atau jasa yangditerima oleh konsumen, akan menimbulkan negative effect yang diyakini akan berpengaruhterhadap loyalitas konsumen.

Menurut Mowen dan Minor (2002) suara konsumen (voice ofcustomer) merupakan refleksi dari harapan konsumen terhadap atribut perusahaan dalammemenuhi kebutuhan konsumen. Hal tersebut dapat berupa pelayanan, jenis 
produk, kualitasproduk, dan sebagainya. Suara konsumen merupakan hal penting bagi perusahaan dalammeningkatkan kepercayaan dan loyalitas konsumen.

Alasan utama kenapa pelanggan beralih ke penyedia lain adalah ketidakpuasan terhadappenyelesaian masalah (Hart et.al., dalam Sasono, 2007).Keluhan seharusnya dipandang sebagai kesempatan untuk belajar, meningkatkanpelayanan, dan mengetahui apa yang benar-benar pelanggan inginkan. Para pelanggan yangsampai mengeluh itu biasanya tertarik memberi kesempatan kepada perusahaan untuk meletakkanberbagai urusan dengan benar. Ini berarti bahwa jika perusahaan menangani keluhan secaraefektif, perusahaan lebih mungkin tetap menguasai pelanggan dan memperbaiki hubungan yangakan berakibat pada loyalitas pelanggan.(Bruce dan Langdon 2004 h.116).

Adapun penelitian terdahulu yang relevan dengan penelitian ini adalah penelitian yang dilakukan oleh Farida Akbar (2006) dengan judul "Pengaruh Citra Perusahaan (Corporate Image) Dan Penanganan Keluhan (Complaint Handling) Terhadap Kepuasan (Satisfaction), Kepercayaan (Trust) Serta Loyalitas Pelanggan (Loyality) Survei Pada Pelanggan Bengkel Servis Resmi Toyota Di Kota Malang”. Yang mana hasil penelitian ini menunjukan bahwa citra perusahaan dan penanganan keluhan berdampak terhadap loyalitas pelanggan.

\section{METODE PENELITIAN}

Penelitian ini termasuk penelitian kuantitatif dengan jenis deskriptif korelasional. Dalam penelitian ini, peneliti akan mendeskripsikan variabel yang akan peneliti jadikan bahan penelitian. Sesuai pendapat Travers dalam Umar (2011: 22), yang menyatakan bahwa "metode penelitian deskriptif bertujuan untuk menggambarkan sifat sesuatu yang tengah berlangsung pada saat riset dilakukan dan memeriksa sebab-sebab dari suatu gejala tertentu". Penelitian dilakukan pada perusahaan yang bergerak dibidang jasa kecantikan Natasha Skin Care Cabang Kota Padang.

Dan lebih lanjutnya peneliti mencoba melihat hubungan dari variabel yang telah peneliti deskripsikan terlebih dahulu, sesuai dengan pendapat Arikunto (2002), yaitu "penelitian korelasi adalah merupakan penelitian yang dimaksudkan untuk mengetahui ada tidaknya hubungan dua atau beberapa variabel, dengan teknik korelasi peneliti dapat mengetahui hubungan satu variabel dengan variabel yang lain".

Dalam penelitian ini yang menjadi populasi adalah seluruh pelanggan yang terdaftar pengguna dan konsumen produk dan jasa kecantikan Natasha Skin Care Cabang Kota Padang. Data penelitian diambil dengan melakukan penyebaran kusioner pada bulan April tahun 2017.

Sampel merupakan sebagian dari jumlah populasi yang dipilih untuk sumber data. Hal ini sesuai dengan pendapat Sugiono (2009: 118), yang berpendapatbahwa "sampel adalah bagian dari jumlah dan karakteristik yang dimiliki dari populasi yang terpilih dan mewakili populasi tersebut". Teknik penarikan sampel yang digunakan dalam penelitian ini adalah dengan menggunakan teknik Simple Random sampling.

Sumber data dipergunakan untuk mencapai tujuan penelitian yang telah ditetapkan, data primer dikumpulkan dari responden yang menjadi sampel. 
Reseponden meliputi sebagian dari jumlah seluruh karyawan. Sedangkan data sekunder diperoleh dari pihak internal perusahaan yakni pada bagian umum dan bagian yang berkaitan dengan penelitian ini di Natasha Skin Care Cabang Kota Padang.Untuk memperoleh data yang pasti maka diperlukan adanya populasi yang diteliti, sebab tanpa adanya populasi akan mengalami kesulitan dalam mengolah data.

Instrumen untuk mengumpulkan data dalam penelitian ini adalah berupa kuesioner yang disusun dengan menggunakan skala Likert. Setiap pertanyaan mempunyai lima alternatif jawaban yang dipilih dengan berdasarkan pada skala likert, untuk memudahkan pengumpulan data maka perlu disusun sebuah kisi-kisi instrumen penelitian, penyusunan kisi-kisi instrumen penelitian ini berdasarkan pada indikator yang ada pada indikator variabel, indikator penelitian didasarkan pada teoriteori yang telah dijelaskan sebelumnya.Uji Validitas untuk mengetahui sejauh mana validitas data yang didapat dari penyebaran kuisioner. Uji validitas ini dilakukan dengan menggunakan bantuan.Uji reliabilitas menunjukkan sejauh mana suatu hasil pengukuran relatif konsisten apabila pengukuran terhadap aspek yang sama pada alat ukur yang sama. Pada penelitian ini uji reliabilitas alat ukur yang akan digunakan adalah dengan menggunakan aplikasi SPSS. Pengujian ini berguna untuk mengetahui apakah pengukuran yang dibuat reliabel.Pada penelitian yang akan dilakukan ini, uji reliabilitas menggunakan aplikasi Cronbach Alpa dari SPSS yang berguna untuk mengetahui apakah pengukuran yang kita lakukan reliabel.

Linear berganda adalah alat statistik yang digunakan untutk mengetahui pengaruh antara satu atau beberapa variabel terhadap satu buah variabel.Variabel yang memengaruhi sering disebut variabel bebas, variabel independen atau variabel penjelas.Variabel yang dipengaruhi sering disebut dengan variabel terikat atau variabel dependen.Regresi linear hanya dapat digunakan pada skala interval dan ratio.

Secara umum regresi linear terdiri dari dua yaitu regresi linear sederhana yaitu dengan satu buah variabel bebas dan satu buah variabel terikat, namun dalam penelitian ini penulis menggunakan regresi linear berganda, karena dalam penelitian ini penulis menggunakan lebih dari satu variabel.

\section{HASIL DAN PEMBAHASAN}

Natasha Skin Care sebagai salah satu pusat perawatan berdiri pada tahun 1999 yakni dengan dibukanya Natasha Skin Care klinik yang pertama di Ponorogo Jawa Timur. Setelah klinik tersebut, disusul dengan pendirian klinik berikutnya di Madiun dan Surabaya pada tahun yang sama dan mendapat respon yang cukup positif dari masyarakat. Respon positif dari pelanggan tersebut dapat dilihat dari perkembangan Natasha Skin Care yang begitu pesat. Dalam kurun waktu enam tahun jaringan klinik Natasha Skin Care pun semakin meluas keseluruh Indonesia (Natasha, 2010). Pusat kecantikan yang berpusat di Jalan Kaliurang Km.5 No.53 Depok, Sleman, Yogyakarta ini, kini telah memiliki 37 cabang di 23 kota di Indonesia.

Komitmen Natasha Skin Care adalah memberikan pelayanan nomor satu di tangan para profesional yang handal. Yogyakarta sebagai kota yang ditetapkan sebagai pusatnya, menunjukkan adanya tanggapan atau respon positif dari warga Yogyakarta itu sendiri. Hal tersebut dapat dilihat dari jumlah pelanggan pada lima cabang yang ada di Yogyakarta telah mencapai 150.000 anggota atau sebesar 17,67 
persen dari sekitar 850.000 orang anggota atau pelanggan Natasha Skin Care di Indonesia. Di kota Padang Natasha Skin Care berdiri pada tahun 2013 yang beralamat di Jl. Veteran No. 65 Purus, Padang Barat.

\section{Tabel}

\section{Hasil Uji Validitas Variabel Citra Perusahaan}

Item-Total Statistics

\begin{tabular}{|l|r|r|r|r|r|}
\hline & $\begin{array}{c}\text { Scale Mean if } \\
\text { Item Deleted }\end{array}$ & $\begin{array}{c}\text { Scale Variance } \\
\text { if Item Deleted }\end{array}$ & $\begin{array}{c}\text { Corrected } \\
\text { Item-Total } \\
\text { Correlation }\end{array}$ & $\begin{array}{c}\text { Squared } \\
\text { Multiple } \\
\text { Correlation }\end{array}$ & $\begin{array}{c}\text { Cronbach's Alpha if Item } \\
\text { Deleted }\end{array}$ \\
\hline P1 & 23.68 & 11.008 & .362 & .190 & .763 \\
P2 & 24.08 & 10.499 & .560 & .368 & .727 \\
P3 & 23.78 & 9.830 & .572 & .337 & .720 \\
P4 & 23.88 & 10.208 & .502 & .329 & .735 \\
P5 & 24.06 & 8.784 & .511 & .310 & .744 \\
P6 & 23.70 & 11.242 & .442 & .231 & .749 \\
P7 & 23.74 & 10.457 & .538 & .324 & .730 \\
\hline
\end{tabular}

Sumber : Data primer yang diolah, 2017

Tabel 2

\section{Hasil Uji Validitas Variabel Penanganan Keluhan}

Item-Total Statistics

\begin{tabular}{|l|r|r|r|r|r|}
\hline & $\begin{array}{c}\text { Scale Mean if } \\
\text { Item Deleted }\end{array}$ & $\begin{array}{c}\text { Scale Variance if } \\
\text { Item Deleted }\end{array}$ & $\begin{array}{c}\text { Corrected Item- } \\
\text { Total Correlation }\end{array}$ & $\begin{array}{c}\text { Squared Multiple } \\
\text { Correlation }\end{array}$ & $\begin{array}{c}\text { Cronbach's Alpha if } \\
\text { Item Deleted }\end{array}$ \\
\hline P1 & 11.72 & 3.274 & .343 & .149 & .664 \\
P2 & 12.12 & 3.056 & .545 & .313 & .541 \\
P3 & 11.82 & 2.856 & .467 & .219 & .583 \\
P4 & 11.92 & 2.943 & .445 & .267 & .598 \\
\hline
\end{tabular}

Sumber : Data primer yang diolah, 2017

Tabel 3

Hasil Uji Validitas Variabel Loyalitas Pelanggan

Item-Total Statistics

\begin{tabular}{|l|r|r|r|r|r|}
\hline & $\begin{array}{c}\text { Scale Mean if } \\
\text { Item Deleted }\end{array}$ & $\begin{array}{c}\text { Scale Variance if } \\
\text { Item Deleted }\end{array}$ & $\begin{array}{c}\text { Corrected Item- } \\
\text { Total Correlation }\end{array}$ & $\begin{array}{c}\text { Squared Multiple } \\
\text { Correlation }\end{array}$ & $\begin{array}{c}\text { Cronbach's Alpha if } \\
\text { Item Deleted }\end{array}$ \\
\hline P1 & 16.90 & 3.566 & .592 & .423 & .540 \\
P2 & 17.02 & 4.060 & .354 & .281 & .653 \\
P3 & 16.74 & 4.154 & .363 & .200 & .647 \\
P4 & 16.80 & 4.162 & .416 & .213 & .624 \\
P5 & 16.54 & 3.928 & .411 & .241 & .626 \\
\hline
\end{tabular}

Sumber : Data primer yang diolah, 2017

Tabel 4

Hasil Uji Reliabilitas

\begin{tabular}{|c|l|l|l|}
\hline No & \multicolumn{1}{|c|}{ Variabel } & Cronbach's Alpha & \multicolumn{1}{|c|}{ Keterangan } \\
\hline $\mathbf{1}$ & Citra Perusahaan & 0,767 & Reliabel \\
\hline $\mathbf{2}$ & Penanganan Keluhan & 0,665 & Reliabel \\
\hline $\mathbf{3}$ & Loyalitas Pelanggan & 0,671 & Reliabel \\
\hline
\end{tabular}

Sumber : Data primer yang diolah, 2017 
Tabel 5

Hasil Analisis Regresi Linier Berganda

\begin{tabular}{|ll|r|r|r|r|r|}
\hline \multirow{2}{*}{ Model } & \multicolumn{2}{|c|}{$\begin{array}{c}\text { Standardized } \\
\text { Coefficients }\end{array}$} & \\
\cline { 3 - 5 } & & $\mathrm{B}$ & Std. Error & Beta & $\mathrm{t}$ & \multicolumn{1}{c|}{ Sig. } \\
\hline 1 & (Constant) & -.815 & .499 & & -1.634 & .106 \\
& X1 & 1.060 & .044 & 1.344 & 23.943 & .000 \\
& X2 & -.550 & .074 & -.419 & -7.456 & .000 \\
\hline
\end{tabular}

a. Dependent Variable: $Y$

Sumber: Data primer yang diolah, 2017

Dari persamaan tersebut dapat ditarik kesimpulan bahwa, konstanta menunjukkan tanpa variabel bebas citra perusahaan dan penangan keluhan maka loyalitas pelanggan yaitu sebesar nilai konstanta yang dihasilkan yaitu ---0,815. Namun jika ada variabel citra perusahaan maka loyalitas pelanggan akan meningkat karena variabel citra perusahaan (X1) memberikan pengaruh positif terhadap loyalitas pelanggan. Sedangkan variabel penanganan keluhan (X2) memiliki pengaruh negatif terhadap loyalitas pelanggan di Natasha Skin Care Padang

Pengujian ini bertujuan untuk mengetahui hubungan signifikan dari masing-masing variabel independen terhadap variabel dependen. Uji t dilakukan untuk memeriksa lebih lanjut manakah diantara kedua variabel independen tersebut signifikan atau tidak terhadap loyalitas pelanggan yang dikemukakan pada tabel 4.15

Dari tabel 4.15 diketahui diperoleh nilai thitung untuk variabel citra perusahaan sebesar 23,943 dengan signifikansi 0,000. Nilai Sig. variabel citra perusahaan (X1) sebesar 0,000<0,05 maka H1 diterima, berarti terdapat pengaruh yang signifikan antara variabel citra perusahaan (X1) terhadap loyalitas pelanggan (Y) di Natasha Skin Care Padang.

Untuk variabel penanganan keluhan terdapat nilai thitung sebesar $(-7,456)$ dengan signifikansi variabel penanganan keluhan (X2) sebesar 0,000>0,05 maka $\mathbf{H 2}$ diterima, berarti terdapat pengaruh yang signifikan antara variabel penanganan keluhan (X2) terhadap loyalitas pelanggan (Y) di Natasha Skin Care Padang..

\section{Tabel 6}

Korelasi dan determinasi

Model Summary

\begin{tabular}{|l|r|r|l|l|r|}
\hline Model & $\mathrm{R}$ & $\mathrm{R}$ Square & $\begin{array}{l}\text { Adjusted R } \\
\text { Square }\end{array}$ & $\begin{array}{l}\text { Std. Error of the } \\
\text { Estimate }\end{array}$ & Durbin-Watson \\
\hline 1 & $.975^{\mathrm{a}}$ & .951 & .950 & .648 & 1.982 \\
\hline
\end{tabular}

a. Predictors: (Constant), X2, X1

b. Dependent Variable: $Y$

Sumber: Data Primer yang diolah, 2017 


\section{Tabel 7}

Hasil Uji F (Simultan)

ANOVA $^{\text {D }}$

\begin{tabular}{|ll|r|r|r|r|r|}
\hline Model & & Sum of Squares & \multicolumn{1}{c|}{ df } & Mean Square & \multicolumn{1}{c|}{ F } & \multicolumn{1}{c|}{ Sig. } \\
\hline 1 & Regression & 788.964 & 2 & 394.482 & 940.717 & $.000^{\mathrm{a}}$ \\
& Residual & 40.676 & 97 & .419 & & \\
& Total & 829.640 & 99 & & & \\
\end{tabular}

a. Predictors: (Constant), X2, X1

b. Dependent Variable: $Y$

Sumber: Data Primer yang diolah, 2017

Berdasarkan hasil penelitian yang diperoleh setelah dilakukan pengujian terhadap 100 orang responden yang merupakan pelanggan yang berkunjung ke Natasha Skin Care Padang maka dapat disimpulkan bahwa variabel citra perusahaan berpengaruh signifikan terhadap loyalitas pelanggan di Natasha Skin Care Padang karena memiliki nilai signifikansi $0,000<0,05$. Hal ini menunjukkan bahwa loyalitas pelanggan semakin baik dengan adanya citra perusahaan yang baik di mata pelanggan Natasha Skin Care Padang. Hasil penelitian ini sejalan dengan penelitian yang dilakukan oleh Nindya (2014) yang meneliti tentang pengaruh penanganan keluhan dan citra perusahaan terhadap loyalitas pelanggan pada pengunjung UNY Hotel dengan hasil penelitian menunjukkan bahwa citra perusahan berpengaruh secara parsial terhadap loyalitas pelanggan pada pengunjung UNY Hotel.

Selanjutnya untuk hipotesis kedua pada penelitian ini diterima karena memiliki nilai signifikansi $0,000<0,05$ sehingga dapat disimpulkan bahwa variabel penanganan keluhan berpengaruh signifikan terhadap loyalitas pelanggan pada Natasha Skin Care Padang. Hal ini menunjukkan bahwa penanganan keluhan yang dapat mempengaruhi loyalitas pelanggan pada Natasha Skin Care Padang. Hasil penelitian ini sejalan dengan penelitian yang dilakukan oleh Nindya (2014) yang menyatakan bahwa citra perusahaan dan penanganan keluhan secara parsial berpengaruh terhadap loyalitas pelanggan. Hasil pengujian hipotesis secara simultan menunjukkan bahwa variabel citra perusahaan dan penanganan keluhan secara bersama - sama berpengaruh signifikan terhadap loyalitas pelanggan Natasha Skin Care Padang.

\section{KESIMPULAN}

Berdasarkan uraian dan hasil analisis pada bab - bab sebelumnya mengenai pengaruh kepemimpinan transformasional dan kompensasi terhadap kinerja karyawan PT Bank Nagari Cabang Siteba dapat diambil kesimpulan sebagai berikut:

1. Natasha skin care adalah salah satu perusahaan yang bergerak dibidang kecantikan yang pada beberapa tahun belakangan mampu"mencuri" hati para pelanggan di tengah maraknya industri jasa perawatan kecantikan.

2. Citra Perusahaan berpengaruh terhadap loyalitas pelanggan Natasha Skin Care Padang karena angka signifikansi sebesar 0,000 lebih kecil dari level of signifikan 0,05 (Sig 0,000<0,05), maka dapat diambil kesimpulan bahwa citra 
perusahaan secara parsial berpengaruh terhadap loyalitas pelanggan Natasha Skin Care Padang (H1 diterima).

3. Penanganan keluhan berpengaruh negatif dan signifikan terhadap loyalitas pelanggan Natasha Skin Care Padang karena angka signifikansi sebesar 0,000 lebih kecil dari level of signifikan 0,05 (Sig 0,000 < 0,05), maka dapat diambil kesimpulan bahwa penanganan keluhan berpengaruh negatif dan signifikan secara

\section{Saran} parsial terhadap loyalitas pelanggan Natasha Skin Care Padang (H2 diterima).

Berdasarkan kepada keterbatasan penelitian yang telah dilakukan maka
diajukan beberapa saran yang dapat memberikan manfaat
positifantaralainsebagaiberikut:

1. Diharapkan kepada peneliti selanjutnya untuk dapat menggunakan penelitian ini sebagai referensi yang nantinya akan memberikan perbandingan dalam melakukan penelitian pada bidang yang sama dimasa yang akan datang.

2. Bagi penelitian agar dapat mengkaji lebih dalam wawasan dan pendalaman pengetahuan dalam manajemen pemasaran khususnya yang berkaitan dengan Pengaruh citra perusahaan dan penanganan keluhan terhadap loyalitas pelanggan.

3. Digunakan sebagai bahan yang bermanfaat untuk menambah pengetahuan serta menjadi referensi bagi perusahaan objek penelitian sebagai dasar pengambilan keputusan.

4. Agar pelayanan pada natasha skin care mengalami peningkatan, setidaknya natasha skin care membuat suatu pelatihan tentang pelayanan yang baik terhadap karyawannya agar dapat diterapkan pada konsumen yang akan menikmati jasa dari natasha skin care serta melakukan evaluasi terhadap karyawan tersebut.

\section{DAFTAR PUSTAKA}

Bramson, Dr. Robert, 2004, Customer Loyalty : 50 Strategi Ampuh Membangun dan Mempertahankan Loyalitas Pelanggan, Jakarta : Prestasi Pustakaraya.

Bruce, Andy dan Langdon, Ken, 2004, Mengutamakan Pelanggan:Putting Customer First, Jogjakarta : Zenith Publisher.

Darsono, Lincen Indahwati, 2004, "Loyalty \& Disloyalty: Sebuah Pandangan Komprehensif Dalam Analisa Loyalitas Pelanggan”. Kinerja, Vol. 8, No. 2, h. 163-173

Ferdinand, Augusty, 2006, Metode Penelitian Manajemen (Pedoman Penelitian untuk Penulisan Skripsi, Tesis, Disertasi Ilmu Manajemen), Semarang: Badan Penerbit Universitas Diponegoro.

Fernandes, Y. D., \& Marlius, D. (2018). Peranan Customer Service Dalam Meningkatkan Pelayanan Kepada Nasabah Pada PT. Bank Pembangunan Daerah Sumatera Barat Cabang Utama Padang. https://doi.org/10.31227/osf.io/wrh3p 
Ghozali, Imam, 2006, Aplikasi Analisis Multivariate dengan Program SPSS, Semarang : Badan Penerbit Universitas Diponegoro.

Griffin, Jill, 2003, Customer Loyalty : Menumbuhkan dan Mempertahankan Kesetiaan Pelanggan, Jakarta : Erlangga.

Jamarnis, S., \& Susanti, F. (2019). Pengaruh Harga Dan Periklanan Melalui Internet Terhadap Keputusan Pembelian Produk Sabun Merek Lux Pada Mahasiswa STIE “KBP” Padang. https://doi.org/10.31227/osf.io/xz3d8

Karsono, Nurul Huda, 2006, "Pengaruh manfaat relasional dan kualitas hubungan terhadap kesetiaan dan komunikasi lisan pelanggan". Jurnal bisnis dan manajemen, Vol. 6, No. 1, h.97-120

Karsono, 2008, "Pengaruh Customer Satisfaction dan Trust terhadap Customer Loyalty sebagai Variabel Moderasi”. Jurnal Bisnis dan Manajemen, Vol. 8, No. 1, h. 1-18

Kotler, Philip dan Keller, Kevin lane, 2009, Manajemen Pemasaran, Jakarta: Erlangga.

Kurniawan, R., \& Susanti, F. (2019). Pengaruh Lifestyle Terhadap Keputusan Pembelian Pada Sepatu Merek Fladeo Di Basko Grand Mall Padang. https://doi.org/10.31227/osf.io/ehyau

Marlius, D. (2018). Loyalitas Nasabah Bank Nagari Syariah Cabang Bukittinggi Dilihat Dari Kualitas Pelayanan. Jurnal Pundi. Volume 1. No. 3. Hal.12-22. https://doi.org/10.31575/jp.v1i3.60

Marlius, D. (2018). Pengaruh Dimensi Kualitas Pelayanan Website Akademik Terhadap Kepuasan Mahasiswa Pada STIE "KBP". Jurnal Ipteks Terapan. Volume 12. No. 2. Hal. 116-128. http://doi.org/10.22216/jit.2018.v12i2.633

Marlius, D. (2017). Keputusan Pembelian Berdasarkan Faktor Psikologis Dan Bauran Pemasaran Pada PT. Intercom Mobilindo Padang. Jurnal Pundi. Volume 1. No. 1. Hal. 57-66. https://doi.org/10.31575/jp.v1i1.9

Marlius, D. (2016). Pengaruh Bauran Pemasaran Jasa Terhadap Minat Nasabah Dalam Menabung Pada Bank Nagari Cabang Muaralabuh. https://doi.org/10.31227/osf.io/vdqgx

Meidisa, C., \& Susanti, F. (2019). Pengaruh Preferensi Dan Pengetahuan Produk Terhadap Minat Menabung Masyarakat Pada Bank Nagari Unit Layanan Syariah Cabang Pasar Raya Padang. https://doi.org/10.31227/osf.io/bf7cr 
Morgan, Robert M., dan Hunt, Shelly D., 1994, “The Commitment - Trust Theory of Relationship Marketing. Journal of Marketing, Vol. 58, No. 7, pp. 20-38

Mowen, John C dan Minor, Michael, 2002, Perilaku Konsumen, Bandung : Gelora Aksara Pratama.

Mulyadi, H., \& Susanti, F. (2018). Pengaruh Penerapan Strategi Customer Relationship Marketing Terhadap Kepuasan Nasabah Pada PT. Pro Car International Finance Cabang Padang. https://doi.org/10.31227/osf.io/bhq8d

Ramadania, 2002, “Kepercayaan dan Komitmen sebagai Perantara Kunci Relationship Marketing dalam Membangun Loyalitas”. Jurnal Riset Ekonomi dan Manajemen, Vol. 2, No. 1, h. 33-52

Sasono, Eko, 2007, “Analisis Faktor-faktor yang Menentukan Kepuasan Pelanggan dan Pengaruhnya terhadap Loyalitas Pelanggan Bank Syariah”, Tesis Tidak Dipublikasikan, Fakultas Ekonomi, Universitas Diponegoro, Semarang

Setyaningsih, Evita, 2009, "Analisis Faktor-faktor yang Mempengaruhi Loyalitas Pelanggan pada Black Canyon Coffee Surabaya", Tesis Tidak Dipublikasikan,Fakultas Ekonomi, Universitas Diponegoro, Semarang

Susanti, F. W Ekazaputri. (2018). Service Performance Dan Kepuasan Sebagai Moderating Variabel Terhadap Loyalitas Nasabah Pada PT BPR Labuh Gunung Payakumbuh Jurnal Benefita: Ekonomi Pembangunan Manajemen Bisnis Dan Akuntansi. Volume 3. No. 3. Hal. 433444.http://doi.org/10.22216/jbe.v3i3.3472

Susanti, F., \& Gunawan, A. C. (2019). Pengaruh Bauran Promosi Dan Harga Terhadap Keputusan Pembelian Produk Kosmetik Maybelline Di Kota Padang. https://doi.org/10.31227/osf.io/npjqh

Tiza, M. F., \& Susanti, F. (2019). Pengaruh Kualitas Pelayanan Terhadap Kepuasan Pelanggan, Studi kasus pada perusahaan JNE Cabang Padang. https://doi.org/10.31227/osf.io/hx87m

Wijaya, Tony, 2008, "Pengaruh Kepuasan pada Penanganan Keluhan dan Citra Perusahaan terhadap Loyalitas Konsumen Natasha Skin Care". Jurnal Ekonomi dan Bisnis, Vol. XIV, No. 1, h. 55-69

Yuniningsih, 2007, "Pengaruh Kepuasan dan Hubungan Pemasaran terhadap Loyalitas Nasabah Beberapa Bank di Surabaya”. Jurnal Manajemen, Akuntansi dan Bisnis, Vol. 5, No. 3, h. 461-466 